\title{
ASIANTUNTIJUUTEEN INVESTOIMINEN KORKEAKOULUTUKSESSA
}

PÄIVITYNJÄLÄ, JUSSI VÄLIMAA \& MARI MURTONEN (toim.) 2004. Korkeakoulutus, oppiminen ja työelämä. Pedagogisia ja yhteiskuntatieteellisiä näkökulmia. PS-kustannus, 294 s.

Teokseen koottujen 15 artikkelin takana on vaikuttava joukko tutkijoita: Sakari Ahola, Kaija Collin, Laura Helle, Antti Kauppi, Kati Laine, Kirsti Lonka (2), Mari Murtonen (2), Mirka Mäkinen, Marja-Liisa NeuvonenRauhala, Juha Nieminen, Erkki Olkinuora, Nina Paganus, Ellen Piesanen, Marja-Leena Stenström, Päivi Tynjälä (4), Anneli Sarja, Virpi Slotte (2), Ulla-Maija Valleala, Sakari Valkonen, Pirkko Vesterinen, Maarit Virolainen ja Jussi Välimaa. Artikkelit jakautuvat viiteen päälukuun (korkeakoulutus osana yhteiskuntaa, korkeakoulutus työelämään valmistajana, työn ja oppimisen vuorovaikutus, teoreettisia malleja työn ja oppimisen yhdistämiseen, ja pedagogisia ratkaisuja). Toimittajien mukaan teoksen lähtökohtana on korkeakoulutuksen yhteiskuntasuhteessa tapahtunut muutos. Mitä ovat asiantuntijuuden tuottamisen ehdot ja edellytykset, kun korkeakoulutukselta odotetaan hyödyllisyyttä työelämärelevanssina. Teoksen toivotaan toimivan virikeaineistona niin korkeakouluissa toimiville opettajille kuin korkeakoulujen opetustarjonnan hyödyntämisestä kiinnostuneille työelämän kehittäjille ja kouluttajillekin.

Ensimmäinen artikkeli jäsentää korkeakoulutuksen ja työelämän suhdetta työmarkkinoiden kautta. Työvoima on inhimillistä pääomaa ja siten investointien kohde työmarkkinaosapuolille. Onnistuneet ja epäonnistuneet investoinnit paljastuvat työmarkkinoilla. Tarjolla on kuitenkin vain ongelmallisia näkemyksiä siitä, miten tämä tapahtuu ja miten työmarkkinat kehittyvät. Tilanne on hankala sekä kouluttautujille, jotka pyrkivät tekemään optimaalisia investointipäätöksiä, kuin myös tutkijoille, jotka yrittävät ymmärtää, miten nuo markkinat toimivat ja investointipäätöksiä toi- 
mintansa kautta arvottavat. Luenkin teoksen artikkeleita koulutusinvestointien näkökulmasta. Näkökulma on siis lukijan, ei kirjoittajien.

\section{KOULUTUKSEN}

INVESTOINTIARVO

\section{SÄÄTELEE}

Kun tarkastelukulma rajataan avoimen yliopiston ja yritysten väliseen yhteistyöhön ja siitä saatuihin kokemuksiin, kuten kokoelman toisessa artikkelissa tehdään, asiat näyttävät selvemmiltä. Hoitotieteen ja ergonomian koulutuksiin resursseja uhranneet osapuolet olivat kokemuksiinsa tyytyväisiä. Hoi-tohenkilökunnan opintoihin investoinut työnantaja kartutti pääomaansa. Tekijä tuo opintojen ansiona esiin mm. sen, että hoitotyöntekijät hahmottavat nyt jäsentyneemmin hoitotieteen perusolemuksen, sen yhteyden arjen työhön ja heillä on aikaisempaa teoreettisempi näkemys hoitotieteestä sekä enemmän kykyä käyttää tutkimustietoa. Vastaavasti yhteistyö koulutuksen tuottajan ja sen käyttäjän välillä ergonomian perusopintojen järjestämisessä vahvisti kumpaakin osapuolta.

Kolmannen tekstin aiheena on työmarkkina-asemaansa parantamaan pyrkivien yliopistoopiskelijoiden kokemukset ja käsitykset omista opinnoistaan sekä niiden yhteys opintoalaan. Jotta opiskelija sitoutuisi opintoihinsa ja opiskelisi motivoituneesti, hänen tulisi kirjoittajan mukaan voida nähdä opinnoista seuraava konkreettinen hyöty hänelle itselleen. Monet yliopistolliset koulutusohjelmat eivät tarjoa koulutukseen investoiville kouluttautujille riittävää informaatiota sen myötä avautuvista uraportfoliomahdolli- suuksista. Ratkaisuksi esitetään mm. ohjausta, yhteistyötä työelämän kanssa ja alumniyhteyksien käyttöä.

Motivaatio oman kompetenssin lisäämiseen, opiskelijan investointi-into, riippuu monista tekijöistä. Orientaatio voi vaihdella (tehtävän ratkaisu, yhteisöön liittyminen, minän puolustaminen), ja vaihtelulla on oma yhteytensä organisaatiotyyppiin ja -kulttuuriin. Tähän edelleen liittyy toimijan käsitys itsestä suhteessa toiminnan kohteeseen. Tällaiset käsitykset eivät ole yhdentekeviä, vaan ne jopa määräävät toimintaa : ”...mutta jos hänen käsityksensä opettamisesta perustuvat vaikkapa ulkoaluvun ideaan, hänen opetuksensa käytännössä tähtää tähän päämäärään. Kyseisen opettajan käsitykset tarvitsevat radikaalia muutosta, ennen kuin hänen käytäntönsä voisivat syvällisesti muuttua.” (s. 82.) Tekijän esimerkki tulee tutkimusmenetelmäopintoihin panostamisesta. Jos kvantitatiivisen otteen oppiminen tuottaa vaikeuksia, sen havaittu investointiarvo laskee, oman minän puolustus nousee ja huomio suuntautuu helposti henkilökohtaisesti kiinnostavampiin kohteisiin.

\section{INVESTOINTIARVO TYÖSTÄ KÄSIN}

Lisää perspektiiviä ilmiöön tuo opintoinvestointien retrospektiivinen tarkastelu työelämästä käsin. Lähtökohtana on valmistuneille tehty kysely. Sen pohjalta luodaan kiinnostava, joskin vaikeasti avautuva kuva työelämän vaatimuksista. Opettajista ja farmaseuteista tulee "ihmissuhdespesialisteja”, osasta opettajia "keskitason generalisteja” ja noin yhdestä kymmenestä kasvatustieteilijästä "korkean tason symbolianalyytikko". Sosiaaliset taidot näyttäytyvät yleisenä vaatimuksena. Yli puolet vastaajista kokee, että tärkeimmät työssä vaadittavat taidot on opittu työssä ja vain reilu kymmenes mainitsee yliopiston niiden lähteeksi. Kuitenkin 63 prosenttia tietojenkäsittelyopista ja farmasiasta valmistuneista katsoo koulutuksen antaneen kokolailla hyvät valmiudet työhön (kasvatustieteessä noin puolet ja 42 prosenttia opettajankoulutuksessa). Tekijöiden mukaan huomiota tulisikin suunnata yleisten taitojen oppimiseen alakohtaisen tiedon lomassa.

\section{INVESTOINTI \\ KOULUTUKSEEN JA TYÖLLISTYMINEN}

Koulutusinvestointien osuvuutta voidaan arvioida työllistymisen vaatiman viiveen ja työstä saadun palkan avulla. Sitä on myös mahdollista lähestyä työllistyneen itsensä näkökulmasta. Kuudes artikkeli tarkasteleekin ammattikorkeakoulusta työelämään ponnistaneita. Työllistyminen kolme vuotta tutkinnon suorittamisen jälkeen on varsin hyvällä mallilla. Yli 62-77 prosentilla toimi alasta riippuen tehtävissä, joissa vaadittiin korkeakoulututkinto. 72-84 prosenttia katsoi toimivansa asiantuntijatehtävissä. Koulutusinvestointien koettiin antaneen valmiuksia teoreettiseen ajatteluun ja jatko-opintoihin. Enemmän olisi tullut laittaa pelimerkkejä kokonaisuuksien hallintaan, epävarmuuden sietoon, ajankäytön hallintaan, vastuullisuuteen ja käytännön ammattitaitoon.

Seitsemäs artikkeli kuvaa inhimillisen pääoman informaalia 
kasvua työssä oppimisena. Tekijät korostavat yhteisöllisyyden ylläpitämisen merkitystä osana työtä. Keskusteluissa rakennetaan ja ylläpidetään jaettuja tulkintakehyksiä ja ratkaistaan yhdessä työhön liittyviä ongelmia. Varsin valaiseva tarkastelu päättyy pohdintaan siitä, miten havaittua olisi mahdollista soveltaa koulutukseen liittyvissä työssäoppimisen jaksoissa.

E-oppimiseen tehtyjen investointien tuotto määräytyy monen eri tekijän summana. Tarkastelun taustana toimii henkilöstönkehittäjien aikuiskasvatuksen verkko-opintoinvestoinnit. E-oppimisen tuottoyhtälössä tarvitaan seuraavia tekijöitä: eri alojen asiantuntijoiden yhteistyö, jaetut tavoitteet, autenttinen yhteys työhön, johdon tuki ja oppijoiden vuorovaikutus. Tekijän mielestä enemmän huomiota pitäisi kiinnittää mm. siihen, "että jokainen työntekijä tunnistaa tarpeen edistää omaa oppimistaan niin, että se liittyy kiinteäksi osaksi organisaation oppimista” (s. 162).

Yhdeksäs artikkeli nostaa esiin koulutuksen infrastruktuuri-investoinnit. Tarkastelun kohteena ovat jatkotutkintojen järjestämislupaa ja rahoitusta valtiolta tavoittelevat ammattikorkeakoulut. Työelämärelevanssin maksimointi- ja työstä poissaoloajan minimointitavoite vie lähelle tilannetta, jossa koulutuksellisista virheinvestoinneista vastaa aina joku muu kuin hyödyt keräävä yritys. Tätä kutsutaan työelämäläheiseksi pedagogiikaksi.

Työelämäläheisempi oppiminen vaikuttaakin kasvavassa määrin ulkoistetulta ja muiden kustantamalta henkilöstökoulutukselta. Seuraavan artikkelin kirjoittaja toteaakin: ”Oppimisympäristön muuttuessa oppilaitoksesta työelämään tarvitaan uudenlaisia tapoja jäsentää oppimista” (s.188). Tekijä nostaa esiin neljä erilaista oppimismuotoa, joista viimeisin, uudistava oppiminen, on syvälle ulottuva ja rajoja murtava yhteistoiminnallinen tiedonluonti- ja muutosprosessi. Haasteena on eri oppimistyyppien yhteensovittaminen kokonaisuuden kannalta tarkoituksenmukaisella tavalla.

\section{OPPIMISEN MALLEJA}

Ammattikorkeakoulujen työelämäyhteyksien luonne työharjoitteluna hahmottuu viiden eri mallin valossa (vierailu, oppiminen, taitojen demonstrointi näyttöinä, käsitteellisen hallinnan malli ja osallisuutta ja rajanylityksiä korostava malli). Eri aloilla ja opintojen eri vaiheissa painotus näiden välillä vaihtelee. Esitellyt mallit tarjoavat selkeän kehyksen, jonka alla arvioida harjoittelukäytäntöjä ja jäsentää kehittämistarpeita.

Ongelmalähtöinen oppiminen työelämään valmentajana markkinoi oppimista osallistumisena, asiantuntijoiden yhteisöön liittymisenä - monopoli on paras voiton tae - ja tiedon luomisena. Ongelmalähtöisyys tarjoaa mahdollisuuden kytkeä opetus tosielämän tapauksiin, mutta opiskelijan oppimisinvestoinnit eivät tapahdu itsestään vaan vaativat tukijärjestelmiä. Teksti myy ennen muuta ongelmalähtöistä oppimista ja vetoaa sen kymmeneen siitä seuraavaan hyvään. Hyvä lisä investointisalkkuun, jos kaipaa sinne kaikki mahdolliset lupaukset sekä moderneja teoriajohdannaisia, käsitevempeleitä ja terminologisia vipuja.
Toiseksi viimeinen artikkeli käsittelee projekti-instrumenttia. "Projektiopinnot ovat askel tai pari todenmakuisempia kuin ongelmalähtöinen oppiminen jopa aitoihin projektitoimeksiantoihin perustuvia” (s. 256257). Tavoitteena on konkreettinen tuotos. Tekijät valottavat projektiopiskelun taustaa, saatuja kokemuksia ja toimintamalleja.

Kokoelman päättävä kirjoitus käsittelee käytännön tuomista yliopistoon sosiaalityöntekijöiden koulutuksessa ja terveydenhoitajan opettajankoulutuksessa dialogia korostavan toiminnan kautta. Kokemuksista keskustelu vaikuttaakin varsin kannattavalta investointikohteelta, kun halutaan vahvistaa ymmärrystä ja tukea sille rakentuvaa käytännön haltuunottoa. Monia tietoyhteiskunnan töitä tehdään puhumalla ja dialogissa.

Teoksessa korkeakoulutuksen ja työelämän suhdetta lähestytään monipuolisesti säilyttäen näkökulma samalla kapeana. Haaste säilyy varsin samana artikkelista toiseen ja saa vaihtelevia painotuksia. Tekijöiden ansio on se, että he ovat ottaneet korkeakoulutuksen kehittämishaasteen kokolailla annettuna ja ryhtyneet konstruoimaan siihen tarkoituksenmukaista ratkaisua pedagogiikan ja oppimisenpsykologian tuoreimpien välineiden ja tutkimushavaintojen avulla. Tuloksena on monia kontribuutioita työelämäläheiseen pedagogiikkaan. Asianmukaista vain olisi poistaa työelämäläheisen pedagogiikan käsitteestä tuo elämä ja puhua päivitetystä palkkatyöläheisestä pedagogiikasta.

\section{Vesa Huotari}

